\title{
Effect of the Energy Drink "Bison" on Mitosis And Nucleic Acids Content In Vicia faba
}

\author{
Norah, H. Al-Zahrani; Asmahan, A. M. Ali \\ and Salha, M. Al-Shamrani. \\ Faculty of Science (Girls), King Abdulaziz University, \\ Jeddah, Kingdom of Saudia Arabia. \\ nlalzhrani@kau.edu.sa
}

\begin{abstract}
The present investigation had been conducted to study the mutagenic effects of four concentrations of energy drink "Bison" (50, 80,90 , and $100 \%$ ) with three exposure times $(6,12$, and 24 hours)on root meristems of Vicia faba plant. Mitotic index was reduced in all treatments except for two treatments: $90 \%$ Bison with two exposure times 6 and $12 \mathrm{~h}$. On the other hand, total abnormalities were highly increased in all treatments. The most common abnormalities were: Stickiness, disturbed, C-metaphase, star shape and lagging chromosomes. In addition, bridges, multipolar, breaks, (micro-multi) nuclii and dinucleated occurred with very low frequencies in some treatments. These results-indicated that Bison had Turbagenic effects. Unbalanced mitotic stages percentages occurred as a result of all treatments compaired with control. Different Bison treatments caused altering of DNA and RNA contents in Vicia faba root tips. The inhibitory effects of most Bison treatments were found to depend on exposure time dose. Hundred percentage Bison treatment for $24 \mathrm{~h}$ caused the highest total abnormalities $(90.32 \%)$ and the lowest content of DNA and RNA (4.63 and $1.98 \mathrm{mg} \backslash \mathrm{g}$ ) respectively compared with respective control $2.12 \%, 9.73$ and $3.26 \mathrm{mg} / \mathrm{g}$ respectively. These findings indicate the mutagenic potentiality of the energy drink "Bison".
\end{abstract}

Keywords: energy drink, mitosis, nucleic auids, metaphase mitotic indet, Bison, mutagenic potentiality. 


\section{Introduction}

Evaluating the toxicity of environmental pollutants by plant materials was further expressed by many workshops ${ }^{[1-3]}$. As a cytogenetic material, Vicia faba has the advantage of having six pairs of relatively large chromosomes that are excellent for assessing chromosomal aberrations $^{[4]}$. Energy drinks are soft drinks advertised as being specifically designed to provide energy. Generally they include a combination of methylxanthines, caffeine, $\beta$-vitamins and herbal ingredients (such as: guarana; taurine, ginseng, inositol, carnitine). Many of energy drinks are not sutiable for children, pregnant women, people has allergic to caffeine, those of heart diseases or high blood pressure and diabetes. The mutagenic potential of energy drinks has not yet been examined, the present investigation was carried out to evaluate the effect of the energy drink "Bison" on mitosis and nucleic acid contents in Vicia faba.

\section{Materials and Methods}

Seeds of Vicia faba (V.Giza 40 ) were treated with energy drink "Bison" produced by Abuljadayel Beverages INC Jeddah, Saudi Arabia. P.O.Box. 3865.

The list of Bison contents are presented in Table 1. Four Bison concentrations corresponding to 50,80, 90 and $100 \%$ were used for 6,12 and $24 \mathrm{~h}$. Water control was maintained for assessment of spontaneous aberrations. After exposure, root tips of 2-3 cm length were excised, fixed in Carnoy solution (3:1 ethanol - acetic acid ) and stored in 70\% alcohol. Aceto - Carmine squash preparations were made and examined cytologically.

Five preparations from each treatment were examined to determine the Mitotic index, mitotic stages percentage, total abnormalities percentage and abnormalities mitotic phases percentage.

On the other hand, DNA and RNA contents from all Vicia faba root tips treatments were isolated by a modified method based on Shibko et al. ${ }^{[5]}$ RNA was estimated by visible spectrophotometry using the orcinol reaction as described by Ashweel ${ }^{[6]}$, while DNA was estimated by the diphenylamine (DPA) colour reaction described by Burton $^{[7]}$. 
Table 1. Nutrition Facts per $100 \mathrm{ml}$ Bison.

\begin{tabular}{|ll|}
\hline Amount per serving: & $13.0 \mathrm{~g}$ \\
Total carbohydrates & $13.0 \mathrm{~g}$ \\
Sugars & $24.0 \mathrm{mg}$ \\
Caffeine & $0.3 \mathrm{mg}$ \\
Taurin & $25.0 \mathrm{mg}$ \\
Vitamin $\mathrm{C}$ & $6.0 \mathrm{mg}$ \\
Niacin & $2.5 \mathrm{mg}$ \\
Panthotonic acid & $0.6 \mathrm{mg}$ \\
Vitamin B6 & $0.053 \mathrm{mg}$ \\
Follic Acid & \\
Calories : $51 \mathrm{kcal} / 212.5 \mathrm{KJ}$. &
\end{tabular}

\section{Results and Discussion}

\section{1-Mitotic Phases Frequencies}

The diferent concentrations of Bison showed a marked effect on the mitotic phases frequency depending on the concentration and exposure time. Prophase \%; Metaphase \%; and (Ana-Telo) \% phases ranged from (9.14 and 34.38\%); (35.15 and 71.24\%) and (19.62 and 40.26\%) respectively, as compared to $22.00 ; 36.85$ and $41.14 \%$, respectively, of the control treatment (Table 2).

\section{2-Mitotic Activity}

Mitotic index was reduced at all Bison treatments, except for $90 \%$ "Bison" at two exposure times (6 and $12 \mathrm{~h}$ ) which have slightly increased $(2.55 \%$ after $6 \mathrm{~h})$. Further depression in the mitotic activity was induced after $50 \%$ "Bison" after $12 \mathrm{~h}$ exposure time $12 \mathrm{~h}$. (2.83\%), while it was $4.70 \%$ in the respective control treatment (Table 2 ).

The inhibition of mitotic activity could be due to the effect of "Bison" on the process of DNA synthesis, which is the essential requirement for the progress of the mitotic activity. The reduction of mitotic activity as a result to DNA synthesis was observed by Kononwicz ${ }^{[8]}$; Dolezel et al. ${ }^{[9]}$; EL-Fiki et al. ${ }^{[10]}$. Chen et al. ${ }^{[11]}$; Polit et $a l .{ }^{[12]}$; Kononwicz, Usciati et al. ${ }^{[13]}$; Ryblaczek and Maszwski ${ }^{[14]}$ in many plants such as Vicai faba; Allium sativum; Allium cepa; Pinus silvestris; and Cicer arietinum after chemicals treatment by caffeine; 2,4dichlorophenoxy acetic acid; hydroxyl urea; indol acetic acid; indol butyric acid; benzyl amino purine; gibbrellic acid; kinetin; naphthalene acetic acid was investigated. 


\section{3-Abnormalities}

The various "Bison" treatments induced a wide range of abnormalities. Total abnormalities percentage were increased gradually depending on increasing of the concentration and the prolonged period of treatment. Highest total abnormalities \% was induced at longest exposure time with highest concentration (100\% Bison with $24 \mathrm{~h}$.) up to $90.32 \%$, However, it was $2.15 \%$ in the respective control treatment (Table 2).

Abnormality \% of the mitotic phases Pro- Meta- Ana and Telo were increased by increasing the exposure time in each Bison concentrate except for abnormal prophase in $80 \%$ "Bison". The highest abnormalities $\%$ of (Pro-Meta-Ana and Telo ) phases \% were recorded at 100\% "Bison" after $24 \mathrm{~h}$ of treatment (Table 3 ).

All mitotic treatments showed that metaphase stage was the most affected one where the maximum percentage of abnormalities were scored (Table 3). These results showed that the "Bison" may affect also chromosomal regular movement toward the formation of the metaphase plate, i.e. they may affect chromosome and kinetochore physical and /or chemical nature.

These results were similar to those obtained by Chen et al. ${ }^{[11]}$; Polit et al. ${ }^{[12]}$; Usciate et al. ${ }^{[13]}$; William and Elizabeth ${ }^{[15]}$; Ryblaczek and Maszwski ${ }^{[14]}$ after treatments of Vicia faba,Cicer arietinm and Zea mays plants with caffeine; benzulamino prine; indol acetic acid; hydroxy urea.

The greatest types of abnormalities induced after Bison treatments Were: stickiness (40.00-90.48\%), disturbed (1.48-42.86\%), C-metaphase (3.82- $12.54 \%)$, lagging chromosome (0.60-7.91\%) and star phase (0.33$11.43 \%)$, Fig. 1 (a-j). The other kinds of abnormalities, i.e. Breaks, bridges, multipolar, (micro-multi) nuclei and dinucleated were found in low frequencies at the same treatments as shown in Table 4 and Fig. 1 (g, i-n).

Stickness was observed in Meta and Ana phases (Fig.1 a, b). Stickness was found to cover the whole chromosomes complement leading to the appearance of chromatin masses where the general appearance of the chromosomes were lost. Chen et al. ${ }^{[11]}$; Polit et al. ${ }^{[12]}$; Usciate et al. ${ }^{[13]}$ and Rybazek and Maszwski ${ }^{[14]}$ attributed such stickiness 
to the process of depolymerization of DNA, thus the chromosome surface becomes sticky.

Similar results were obtained after treatment of some plants with many chemicals such as caffeine, benzyl aminopurine; indol acetic acid and hydroxy urea ${ }^{[11-15]}$. On the other hand, disturbed chromosomes were shown in Pro-Meta- and Ana- phases (Fig 1:d- g and j) as a partial action on "Bison" treatments on the spindle formation. Therefore some chromosomes lost their ability to attach with the spindle fiber. Whereas, complete action of "Bison" treatments on the spindle formation resulted in $\mathrm{C}$-metaphase in where the chromosomes lost their ability to continue to anaphase and arrested at metaphase (Fig1, c). Lagging chromosomes were observed in Meta- Ana-and Telo- phases (Fig.1, f, g and i). Occurrence of Laggards at metaphase may result from hinderance of the prometaphase movement of the chromosomes accompanied by adhesion of the centromeres to the adjacent inner surface of the plasma membrane. The Laggards observed at metaphase failed to move properly toward poles and consequently, they appeared at following stages. These results are in agreement with that reported by some workers ${ }^{[11-17]}$.

\section{4-DNA and RNA Contents}

DNA and RNA contents were slightly increased or decreased after Bison treatments except at $100 \%$ Bison for 12 and $24 \mathrm{~h}$ of treatment, which caused marked decreasing of DNA and also after $6 \mathrm{~h}$ for RNA contents (Table 5).

Many chemicals such as nicotine; food flavor; food colorant; water extracts of some umbelliferous plants, and caffeine caused alteration of DNA and RNA contents ${ }^{[11,16,18-20]}$.

Acording to these results, we can conclude that Bison has antimitotic agents which caused imbalance in mitotic phases frequencies, reduction of mitotic index in most treatments, alteration of DNA and RNA contents, marked levels of abnormalities. The inhibition effects of Bison treatments were found to be exposure time dependent rather than exposure dose dependent.

On the other hand, "Bison" has highly potent turbogenic effects (spindle poison) whereas, the greatest types of abnormalities were stickiness, disturbed, C-metaphase and lagging chromosome. These 
effects may be due to some components in Bison such as :- caffeine, taurin, niacin and panthotonic acid.

Table 2. Mitotic phases percentage,mitotic index and total percentage of abnormalities in Vicia faba root tips treated with energy drink ((BISON)).

\begin{tabular}{|c|c|c|c|c|c|c|c|c|c|c|c|}
\hline \multicolumn{2}{|c|}{ Treatments } & \multirow{2}{*}{ 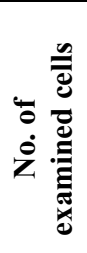 } & \multirow{2}{*}{ 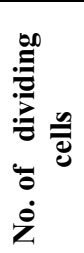 } & \multirow{2}{*}{ 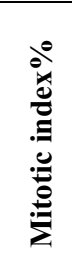 } & \multicolumn{2}{|c|}{ Prophase } & \multicolumn{2}{|c|}{ Metaphase } & \multicolumn{2}{|c|}{$\begin{array}{c}\text { (Ana-Telo) } \\
\text { phase }\end{array}$} & \multirow{2}{*}{ 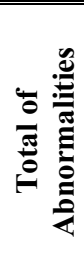 } \\
\hline 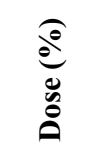 & 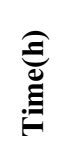 & & & & No. & $\%$ & No. & $\%$ & No. & $\%$ & \\
\hline \multicolumn{2}{|c|}{ control } & 11890 & 559 & 4.70 & 123 & 22.00 & 206 & 36.85 & 230 & 41.14 & 2.15 \\
\hline \multirow{3}{*}{$50 \%$} & 6 & 7926 & 350 & 4.42 & 116 & 33.14 & 152 & 43.43 & 82 & 23.43 & 10.00 \\
\hline & 12 & 8201 & 232 & 2.83 & 59 & 25.43 & 114 & 49.14 & 59 & 25.43 & 46.12 \\
\hline & 24 & 9065 & 313 & 3.45 & 36 & 11.50 & 151 & 48.24 & 126 & 40.26 & 64.86 \\
\hline \multirow{3}{*}{$80 \%$} & 6 & 8567 & 404 & 4.72 & 125 & 30.94 & 142 & 35.15 & 137 & 33.91 & 42.57 \\
\hline & 12 & 8622 & 347 & 4.02 & 65 & 18.73 & 164 & 47.26 & 118 & 34.01 & 66.57 \\
\hline & 24 & 9514 & 305 & 3.21 & 38 & 12.46 & 161 & 52.79 & 106 & 34.75 & 82.95 \\
\hline \multirow{3}{*}{$90 \%$} & 6 & 9296 & 448 & 4.82 & 154 & 34.38 & 170 & 37.95 & 124 & 27.67 & 46.21 \\
\hline & 12 & 10050 & 566 & 5.63 & 132 & 23.32 & 256 & 45.23 & 178 & 31.45 & 61.48 \\
\hline & 24 & 10577 & 324 & 3.06 & 47 & 14.51 & 192 & $\overline{59.26}$ & 85 & 26.23 & 80.86 \\
\hline \multirow{3}{*}{$100 \%$} & 6 & 9638 & 355 & 3.68 & 87 & 24.51 & 169 & 47.61 & 99 & 27.89 & 34.65 \\
\hline & 12 & 9472 & $\begin{array}{l}400 \\
\end{array}$ & 4.22 & 74 & 18.50 & 207 & 51.75 & 119 & 29.75 & 75.75 \\
\hline & 24 & 9895 & 372 & 3.76 & 34 & 9.14 & 265 & 71.24 & 73 & 19.62 & 90.32 \\
\hline
\end{tabular}

Table 3. Abnormal mitotic phases percentages in Vicia faba root tips treated with energy drink "Bison".

\begin{tabular}{|c|c|c|c|c|c|c|c|}
\hline \multicolumn{2}{|c|}{ Treatments } & \multicolumn{2}{|c|}{ Prophase } & \multicolumn{2}{|c|}{ Metaphase } & \multicolumn{2}{|c|}{ (Ana-Telo) phase } \\
\hline Dose\% & Time (h) & NO. & $\%$ & No. & $\%$ & No. & $\%$ \\
\hline \multicolumn{2}{|c|}{ control } & 1 & 0.81 & 6 & 2.91 & 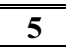 & 2.17 \\
\hline \multirow{3}{*}{$\% 50$} & 6 & 5 & 4.31 & 24 & 15.79 & 6 & 7.32 \\
\hline & 12 & 7 & 11.86 & 73 & 64.04 & 27 & 45.76 \\
\hline & 24 & 7 & 19.44 & 113 & 74.83 & 83 & 65.87 \\
\hline \multirow{3}{*}{$\% 80$} & 6 & 39 & 31.20 & 83 & $\mathbf{5 8 . 4 5}$ & 50 & 36.50 \\
\hline & 12 & 34 & $\begin{array}{l}52.31 \\
\end{array}$ & 131 & 79.88 & 66 & $\overline{55.93}$ \\
\hline & 24 & 14 & 36.84 & 150 & 93.17 & 89 & 83.96 \\
\hline \multirow{3}{*}{$\% 90$} & 6 & 29 & 18.83 & 123 & 72.35 & 55 & 44.35 \\
\hline & 12 & 39 & 29.55 & 203 & 79.30 & 106 & 59.55 \\
\hline & 24 & 20 & 42.55 & 171 & 89.06 & 71 & 83.53 \\
\hline \multirow{3}{*}{$\% 100$} & 6 & 18 & 20.69 & 65 & 38.46 & 40 & 40.40 \\
\hline & 12 & 39 & 52.70 & 180 & 86.96 & 84 & 70.59 \\
\hline & 24 & 19 & 55.88 & 256 & 96.60 & 61 & 83.56 \\
\hline
\end{tabular}


Table 4. Percentage of different types of abnormalities in Vicia faba root tips treated with energy drink " Bison".

\begin{tabular}{|c|c|c|c|c|c|c|c|c|c|c|c|}
\hline \multicolumn{2}{|c|}{ Treatments } & \multirow{2}{*}{ 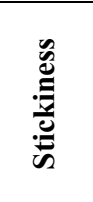 } & \multirow{2}{*}{$\sum^{\prime}$} & \multirow{2}{*}{ 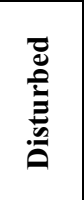 } & \multirow{2}{*}{ 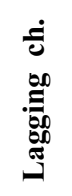 } & \multirow{2}{*}{ 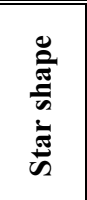 } & \multirow{2}{*}{ 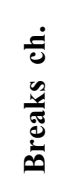 } & \multirow{2}{*}{ 总 } & \multirow{2}{*}{ 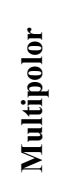 } & \multirow{2}{*}{ 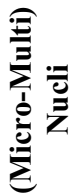 } & \multirow{2}{*}{ 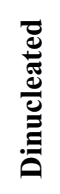 } \\
\hline $\begin{array}{c}\text { Dose } \\
(\%)\end{array}$ & $\begin{array}{c}\text { Time } \\
\text { (h) }\end{array}$ & & & & & & & & & & \\
\hline \multicolumn{2}{|c|}{ Cntrol } & 0.18 & 0.18 & 1.79 & - & - & - & - & - & - & - \\
\hline \multirow{3}{*}{$\% 50$} & 6 & 40.00 & 5.71 & 42.86 & - & 11.43 & - & - & - & 一 & 0.03 \\
\hline & 12 & 52.34 & 4.67 & 35.51 & 0.93 & 5.61 & - & 0.93 & - & 一 & 0.09 \\
\hline & 24 & 64.53 & 4.43 & 24.64 & 2.47 & 1.46 & - & 2.47 & - & 0.01 & 0.10 \\
\hline \multirow{3}{*}{$\% 80$} & 6 & 75.58 & 8.15 & 9.30 & 4.65 & 1.16 & - & 0.58 & 0.58 & 一 & 0.15 \\
\hline & 12 & 59.74 & 12.12 & 13.00 & 7.79 & 1.73 & - & 3.90 & 1.73 & 0.02 & 0.11 \\
\hline & 24 & 67.19 & 7.51 & 9.49 & 7.91 & 1.98 & 0.40 & 3.16 & 2.37 & 0.01 & 0.20 \\
\hline \multirow{3}{*}{$\% 90$} & 6 & 68.60 & 4.35 & 20.29 & - & 4.35 & - & - & 2.42 & 0.03 & 0.46 \\
\hline & 12 & 67.82 & 6.03 & 14.66 & 6.61 & 1.43 & 0.29 & 2.59 & 0.57 & 0.01 & 0.20 \\
\hline & 24 & 84.35 & 3.82 & 4.58 & 3.44 & 1.53 & - & 1.91 & 0.38 & 0.02 & 0.27 \\
\hline \multirow{3}{*}{$\% 100$} & 0 & 66.67 & 4.88 & 25.20 & 1.63 & 1.63 & - & 一 & - & - & 0.02 \\
\hline & 12 & 72.28 & 12.54 & 10.56 & 2.64 & 0.33 & - & 0.99 & 0.66 & 0.02 & 0.14 \\
\hline & 24 & 90.48 & 5.07 & 1.48 & 0.60 & 0.89 & - & 1.48 & - & 0.01 & 0.11 \\
\hline
\end{tabular}

Table 5. Nucleic acids content (DNA and RNA) in Vicia faba root tips treated with energy drink " Bison".

\begin{tabular}{|c|c|c|c|c|c|}
\hline \multicolumn{2}{|c|}{ Treatments } & \multicolumn{2}{|c|}{ DNA } & \multicolumn{2}{|c|}{ RNA } \\
\hline Dose\% & Time(h) & Value* & Difference & Value* & Difference \\
\hline \multicolumn{2}{|c|}{ Control } & 9.73 & 100.00 & 3.26 & 100.00 \\
\hline \multirow{3}{*}{$\% 50$} & 6 & 12.56 & 129.09 & 3.42 & 104.91 \\
\hline & 12 & 10.75 & 110.48 & 2.92 & 89.57 \\
\hline & 24 & 9.73 & 100.00 & 3.60 & 110.43 \\
\hline \multirow{3}{*}{$\% 80$} & 6 & 10.24 & 105.24 & 3.26 & 100.00 \\
\hline & 12 & 9.78 & 100.51 & 2.34 & 71.78 \\
\hline & 24 & 12.56 & 129.09 & 2.36 & 72.39 \\
\hline \multirow{3}{*}{$\% 90$} & 6 & 9.41 & 96.71 & 3.38 & 103.68 \\
\hline & 12 & 9.27 & 95.27 & 3.33 & 102.15 \\
\hline & 24 & 9.18 & 94.35 & 3.24 & 99.39 \\
\hline \multirow{3}{*}{$\% 100$} & 6 & 9.96 & 102.36 & 2.16 & 66.26 \\
\hline & 12 & 6.12 & 62.90 & 2.04 & 62.58 \\
\hline & 24 & 4.63 & 47.58 & 1.98 & 60.74 \\
\hline
\end{tabular}

*Results are expressed as $\mathrm{mg} / \mathrm{g}$ fresh weight. 
88

a

d
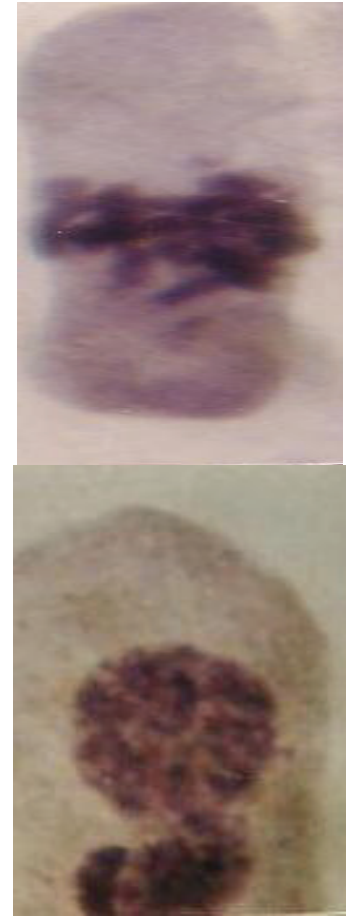

g

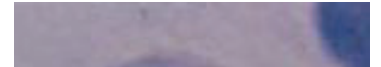

h
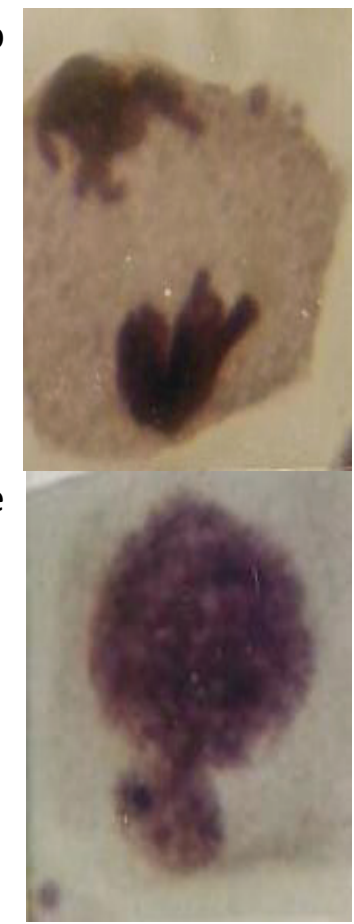

e

Norah H. Al-Zahrani et al.

C

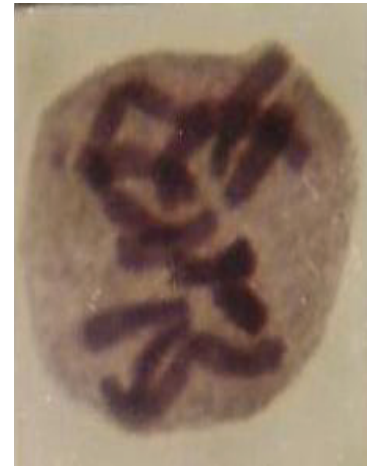

f

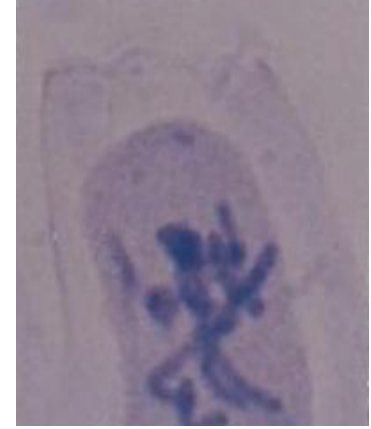

i

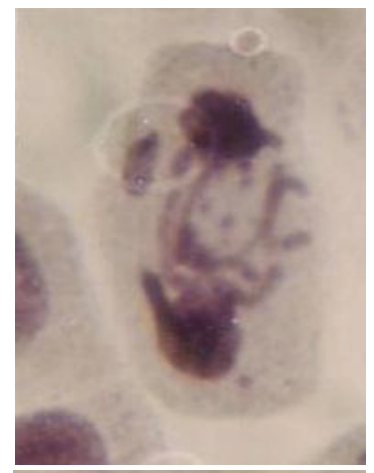

L

k

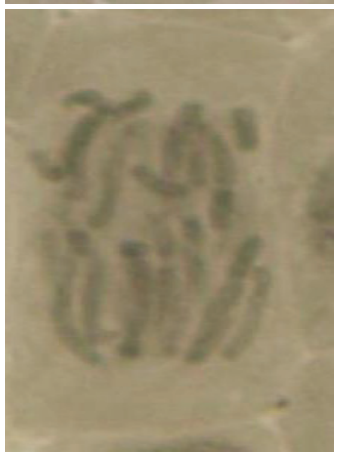

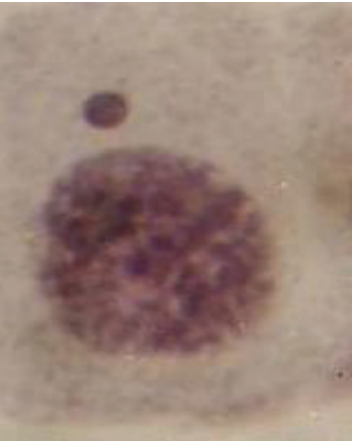


n

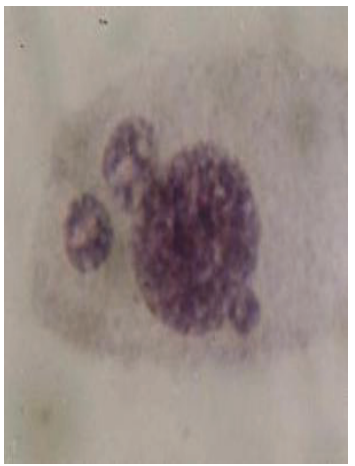

n

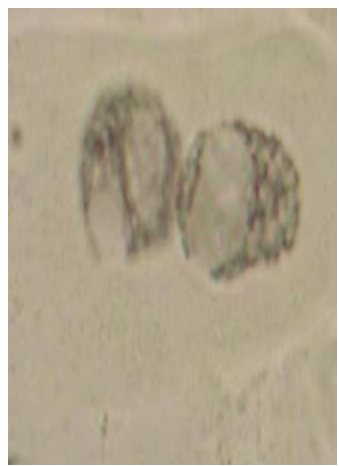

Fig. 1. a,b: Stickinss at (meta and ana) phase; c: C-meta phase; d,e: disturbed prophase; f: disturbed with lagging at metaphase; g: disturbed with lagging and bridge at anaphase ; h: star metaphase; i: telophase bridge with lagging and break ; $\mathrm{j}$ : disturbed anaphase with break; k: micronuclii at prophase; l: micronuclii at interphase ; $\mathbf{m}$ : murltinuclii at intenphase; $n$ : dinucleated .

\section{Refrences}

[1] Shoemaker, R.C.; Amberger, K.A.; Palmer, R.G. and Ranch, J.P., Effect of 2, 4dichlorophenoxy acetic acid concentration on somatic embryogenesis and heritale variation in soybean (Glycine Max L. Mer. R.) in vitro. Cell. Dev. Bio., 27: 84-88 (1991).

[2] Kanaya, N.; Gill, B.S.; Grover, I.S.; Murin, O.R.; Sandhu, S.S. and Andersson, H.C., Vicia faba chromosomal aberration assay.Mutation Research, 310: 231-247 (1994).

[3] Bushra Ateeq, M.A; Niamat, M.A. and Waseem, A., Clastogenicity of penta chlorophenol, 2, 4-D and butachlor evaluated by Allium root tip test. Mutation Research,510: 105113(2002).

[4] Kilman, B.A., Root tips of Vicia faba for the study of the induction of chromosomal aberration. Mutation Research, 13: 105-115 (1975) .

[5] Shibko, S.; Koivisloninen, P.; Tranyek, C.A.; Newhall, A.R. and Friendman, I., A method for sequential quantitative separation and determination of protein ,RNA, DNA, lipid and glycogen from a sigle rat liver homogenate or from a subcellular fraction. Academic Press, New York,). 19(3): 514-528 (1967).

[6] Ashwell, G., Colorimetric analysis of sugar. In: Methods in Enzymology, Academic Press, New York, 3: 73-74 (1957).

[7] Burton, K., A study of the condition and mechanism of the diphenylamine reaction for the colormetic estimation of DNA. J. Bio. Chem. 26: 315-323 (1968).

[8] Kononowicz, H., Cytological study of inhibitory effects of IAA on the root growth in the Pinus silvestris. Folia. Histochem., 16(2): 109-22 (1978).

[9] Dolezel, J.; Lucreff, S. and Novak, F.J., The influence of 2, 4 dichlorophenoxy acetic acid (2, 4-D)in cell kinetic and sister chromatid exchange frequency in garlic (Allium sativum) meristems cells. Bio.Plant., 29: 253-293 (1987).

[10] El-Fiki, A.A.; Asmahan, A.M. and El-Morsy, S.H., Cytigenetical studies on the effects of some hormones and regulators on root meristems of onion (Allium cepa L) .Al-Azhar $J$. Agric. Res., 29: 83-90 (1999).

[11] Chen,Y.; Zhang, L.; Zhou, Y. and Chen, Z., Inducing somatic meiosis like reduction at high frequency by caffeine in root tip of Visia faba. Mutation Research, 20(1): 67-72 (2000). 
[12] Polit, J.T.; Maszewki, J. and Kozmierezak, A., Effect of BAP and IAA on the expression of G1, and G2 control pionts and G1-S and G2-M transition in root meristem cells of Vicia faba. Cell Boil. Int., 27(7): 559-66 (2003).

[13] Usciate, M.; Codaccioni, M. and Guern, J., erly cytological and biochemical events induced by 6-benzylaminopurine application on inhibited axillary buds of Cicer arietinum plant. J. Experimental Botany, 23: 1009-1020 (2004).

[14] Ryblaczek, D. and Maszwski, J., Phosphorylation of H2AX histones in response to double -stand breaks and induction of premature treated root meristem cells of Rephonus sativs, Vicia faba and Allium porrum. Protoplasma, 230(1-2): 31-39 (2007).

[15] Willim, F.G. and Elizabeth,T.O., Zea mays assay of chemical and radiation genotoxicity for the study of environmental mutagens. Mut. Res., 613: 17-64 (2006).

[16] Sunhereer, A.R.; Muthmaran, S.; Devipriya, N. and Menon,V.P., Ellagic acid, anatural polyphenol protects peripheral blood lymphocytes against nicotine induced cellular and DNA damage in vitro with the comparison of $\mathrm{N}$ acetylcystine. Toxicology, 25: 230 (1): 1121 (2007).

[17] Kocaman, A.Y. and Topaktas, M., Genotoxic effects of a particular of acetamiprid and alpha-cypermethrin on chromosome aberration, sister chromatid exchange and micronucleus formation in human peripheral blood lymphocytes. Environ. Toxicol, 330: 193-199 (2009).

[18] Ma, T.E. and Ma, T.H., The international program on plant bioassays and the report of the follow up study after the hand on workshop in china. Mutation Research, 426(2): 103-106 (1999).

[19] Nagwa, R.H., Cytogenetic effects of water extracts of some umbelliffrous plant on Vicia faba. Ph. D. Fac. of Science, Ain Shams Univ.Egypt (2001).

[20] Hala, R.A., Cytological and Molecular studies on the effects of a food flavor and a food colorant and their interaction with vitamin C in plant cells. Ph.D. Fac. of Science. Ain Shams Univ. Egypt (2005). 
تأثير مشروب الطاقة "بايسن" على الاتقسام الميتوزي و محتوى الأحماض النووبة فى نبات الفول

نورة حسن الزهرانى، و أسمهان أحمد محمود على، و صالحة مسفر الثمرانى كلية العلوم للبنات، جامعه الملك عبد العزيز، المدلكة العربية السعودية

الستخلص: تم في هذا البحث دراسة التأثير الطفرى لأربع تركيزات

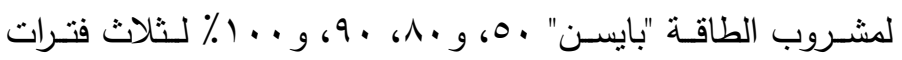

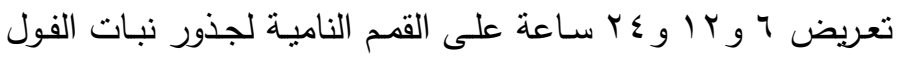

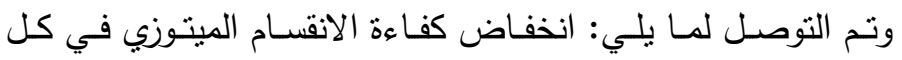

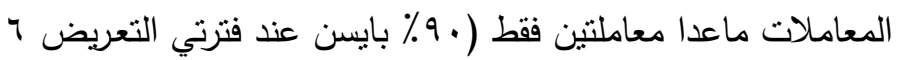

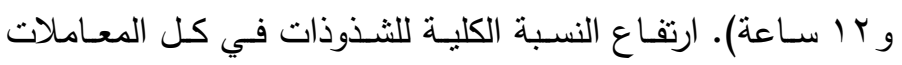

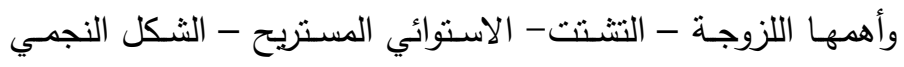

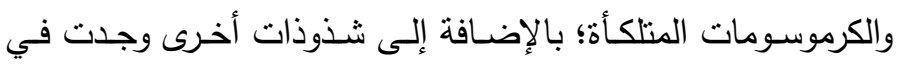

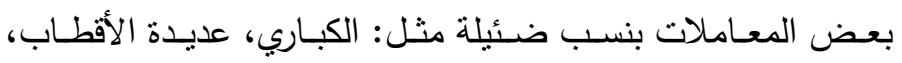

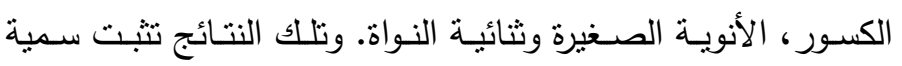

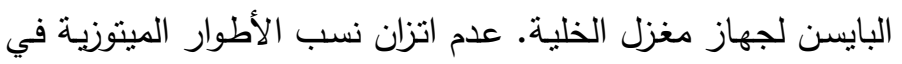

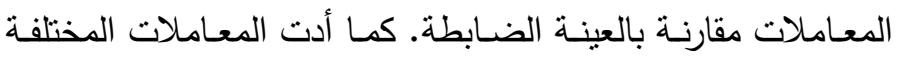

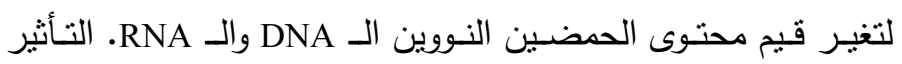

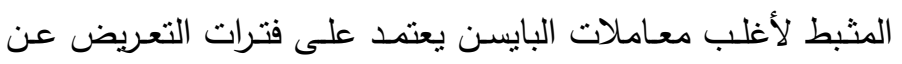

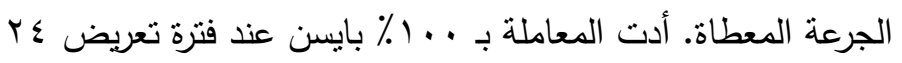

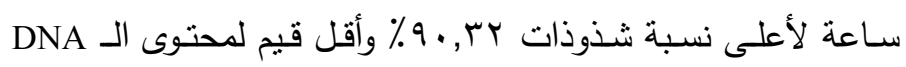

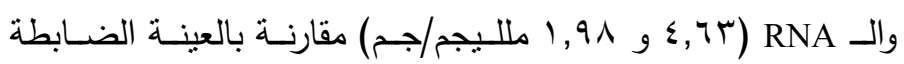

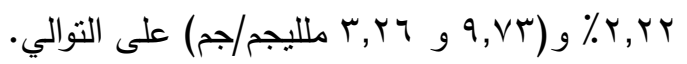

